\title{
Operational Risks and Equity Returns: Dynamic and Static Panel Data Analyses
}

\author{
Theophilus Anaekenwa Aguguom Ph.D. \\ Department of Accounting and Finance \\ Augustine University, Ilara Epe- Lagos State, Nigeria
}

Tel: 23-481-2222-1167 E-mail: theophilus.aguguom@augustineuniversity.edu.ng

Received: July 17, 2020 Accepted: Oct. 13, $2020 \quad$ Published: December 1, 2020

doi:10.5296/ajfa.v12i2.17362 URL: https://doi.org/10.5296/ajfa.v12i2.17362

\begin{abstract}
This study investigated the effect of operational risk on equity returns of Deposit Money Banks (DMBs), using a population consisted of 19 listed deposit money banks in the Nigeria Stock Exchange. 15 DMBs were purposively selected for a period of 15 years 2005 to 2019 . Descriptive and inferential statistics were explored for the data analysis which was sourced from the published financial statements of the banks, using dynamic and static panel data. Diagnostics tests were carried out since the application of the Hausman test provided the criteria for choosing between Random Effect Models and Fixed Effect Models. Breusch and Pagan Lagrangian multiplier test was employed to confirm the Hausman test results in order to decide between Random Effects and Pooled OLS. Correlation Matrix for multicollinearity test and cross-sectional dependent test were equally carried out for the study. Three models were estimated, based on the three proxies of the dependent variable. The study found that operational risk had a statistically positive significant effect on return on equity (ROE), while operational risk equally exhibited statistically positive significant effect on ROA. When the controlling variable of FSIZE was introduced, the study exhibited stronger effects which demonstrates that operational risk had a statistically positive effect on ROE, while operational risk with FSIZE had a statistically positive effect on ROA. The study recommends that DMBs managers should carefully carry out due diligence on loan applicants, to ascertain performance trend and creditworthiness of potential and prospective borrowers before advancing loans in order to reduce huge profiles of credit risk exposures.
\end{abstract}

Keywords: Credit risk, Equity returns, Liquidity risk, Operational risk, Return on assets. 


\section{Introduction}

Managerial incompetence, and unhealthy punitive distortions of financial surveillance are influencing huge gaps in robust equity returns in deposit money banks in Nigeria. Creation of artificial debts, huge nonperforming loans, weak due-diligence practices, and inadequate professional proficiencies are the hallmarks behind non-sustainable equity returns in the Nigerian banks (Adesina, Olufuwobi \& Ayinde, 2018; Ogbuagu, Ubi \& Effiom, 2014). Financial institutions have become more technological reliant on their operations, making operational risk management correspondingly less prioritized, as the banks now rely on new technologies that depend on non-reliable, and epileptic power supplies (Azejiofor, Adigwe \& John-Akamelu, 2015; Olalere \& Wan, 2018). Porous internal control systems and unidentified inherent risks shrink equity returns expectations (Aguguom, 2020; Aguayo \& Slusarczyk, 2020; El-Ansary, 2019).

Basel III identified some basic concerns in risk cases such as Physical Capital (PC). PC incorporates damage to tangible assets, operational and service disruptions, system malfunctions, execution, delivery problems and managerial ability concerns. Basically, the main concern here is technological failures in relation to the banks' computer systems. Another identified basic concern in operational risk is in the area of Human Capital Error which refers to intentional human error and irrational behavior of employees. This type of error includes employment practices mismatch, health and safety employee's hazards and internal fraud. These human capital errors which are prevalent in financial institutions tend to are compounding operation risks characteristic (Buckova \& Reuse, 2011; Kariuki \& Peddy, 2017; Chaikovskyi \& Kovlchuk, 2019).

Gary (2016) documented that the evidence from the various financial crisis in the financial institutions have shown that the guidelines operated at prior years were insufficient to protect the banking and other financial institutions from failure. It was observed that an extreme debt profile, inadequate equity funding, and illiquidity challenges were some of the deficiencies that deepened the severity of the financial crisis. In an effort to alleviate effects and reduce the frequency of financial crisis and/or avoid them, Basel III regulatory reform became introduced (Gelter, 2009, Gary, 2016).

The Basel II and Basel III agreements have a far-reaching influence on shareholders wealth maximization and equity returns, as a change in the equity requirements has an effect on the equity returns performance measures of the bank managers (Institute of Company Secretaries of India, 2016). As expected, higher equity capital influences higher dividend payment and increases earnings per share. Basically, Basel III is a major post-crisis response to the problem of supervising banks, following high profile financial crisis. Basel III represents a substantial change on the Basel II regulatory guidelines, with the objective of having a strong regulatory framework that will ensure strong and adequate equity capital base for the institutions (Bank International Settlement, 2013; Sharfman, 2013). Consequently, the intension of a new Basel III is to take care of the lapses that Basel II could not address, and as a result, institute more vibrant and sufficient regulations that will ensure adequate shareholders' equity capital and excellently handle unforeseen and contingencies. 


\section{Literature Review}

\subsection{Operational Risk}

Operational risk is crucial and has become of increasing concern to bank regulations and the regulations of other financial institutions. The operational risk which arise from mistakes, incompetence, criminal acts, qualitative and quantitative unavailability of employees, failure of technical systems, and dangers resulting from external factors such as external fraud, violence, physical threats or natural disasters as well as legal risk can be countered (Nabweteme, 2015). One way financial institutions can, effectively, ameliorate operational risks is to invest a substantial amount of funds in the creation of a vigorous and viable framework. Also, this involves collaborations from all banks because the highest threats to banks are coming from external events that are not controllable. Thus, a single bank effort will not be sufficient to mitigate operational risks. As a result, the joint actions of all participants in the market are required for effective operational risk management. One of the possible solutions could be the exchange of risk events data between banks within the same system and putting in place a protocol for blacklisting clients. However, this is a problem because banks are reluctant to share data or in house information (Knežević, 2013; Maixe-Altes, 2019).

Contrastingly, one strange phenomenon of operations risk is that it may not be evident in the reported figures on banks. However, its negative effects on banks' performance may develop suddenly and might also be of huge catastrophic dimensions. Recently Nigerian banks posted an improvement in their financial performance but a Fitch 2018 report pointed out an existing risk surrounding most Nigerian banks' performance and even survival. Also, higher US dollars were used to offset rising impairment charges. In addition, large earnings were non-recurring. The Moody report of 2018 also showed similar reports but expressed that there is an increasing rise in loan risk and worsening asset quality (Aguguom \& Olaoye, 2018; Isoh, Amnang \& Nchang, 2020).

\subsection{Equity Returns}

Equity returns are the whole essence of equity capital investment as aligned to shareholders' wealth maximization model (SWM). Shareholders wealth maximization, contextually, implies the principles that advocate corporate objective or that the main objective of companies is to maximize equity holders' wealth and ensure that all management decisions be tailored towards achieving this objective. By implication, other objectives of the entity should be jettisoned and groups interest be exploited for this singular purpose (Fox \& Lorsch, 2012). Critics had advanced that shareholders' wealth or equity holders' returns-maximization model do exist theoretically and dogmatically, rather they are underlying economic agenda of the managers. Incidentally, managers are persuaded and highly motivated to carry out decisions to maximize equity returns for many reasons. These reasons include firstly, to protect and retain their managerial positions; and secondly, to target higher bonuses which results from higher earnings, and thirdly, for their individual interests as managers. To achieve expected equity returns, the managers take decisions that will yield quick returns, engage in discretionary and earning management through privileged information, information asymmetry, insider dealings, manipulating stock prices, and bonus incentives. Equity returns on an asset is the most 
widely-used measure of performances, and this assists banks and other financial institutions in assessing their ability to satisfy equity capital holders' expectations (ICAN, 2014).

\subsection{Credit Risk}

Against the backdrop of the recent events, credit risk is considered one of the single source of risk for most financial institutions and in particular deposit money banks in Nigeria and other developing economies (Aguguom \& Olaoye, 2019; Gadzo, Kportorgbi \& Gatsi, 2019). It has been a significant factor in many bank failures and unceremonious collapses, near-collapses and financial system crisis (Jones \& Will, 2013). Credit risk management is essentially expedient for financial institutions managers because it determines several important features of loans such as interest rate, maturity and collateral. As credit risks get potentially riskier, projects such as loans and advances require a more in-depth analysis and evaluation before they are approved. Apparently, if credit risk is inadequate, default rates would be higher and push financial institutions into insolvency. This is with particular reference to situations where the markets are competitive and the margins are low, especially, among banks in emerging economies.

\subsection{Insolvency Risk}

As operational risk is devastating and capable of destabilizing an institution. Thus, one of the protections against operational risk is to mitigate against insolvency risk and reduce failures in financials' institutions capital (Pracoyo \& Imani, 2018; Nurlida, 2017). Adequate equity capital is capable of absorbing unanticipated loses if there is enough margin to inspire confidence and enable the financial situations to continue as a going entity (Aguguom \& Salawu, 2018). Adequate capital of a financial institution, ultimately, offers protections for uninsured depositors, bondholders, and creditors, in the event of insolvency and liquidation.

\subsection{Empirical Review}

Mostafa, Mahmoud, Jalal and Elahe (2016) conducted a study to determine the relationship between financial risk and profitability of the banks listed in the Tehran Stock Exchange. The study advanced three hypotheses and sought to determine the relationship between financial risk proxied with return on equity, return on assets, and return on capital. The study collected data from 8 sampled private banks of karafarin, Eghtesad Novin, Parsian, Pasargad, Saman, sarmayeh,shahr and the Sina for a period of 5 years (2000-2015). The study found that there was a significant negative relationship between financial risk and profitability of the banks listed on the Tehran Stock Exchange.

In a study, Muhammad and Abdul (2017) examined the factors affecting risk and performance in the banking institution and identified key factors influencing risk in bank operation in Malaysia. The performance of OCBC Bank from the year 2011 to 2015 showed unfavorable performance of liquidity and operational risk. The study, among others, found that banks were not effective in terms of converting their asset into cash in order to make debt settlements. Also, the banks did not efficiently manage their expenses and, expectedly, it negatively impacted the banks' profit performance. Return on assets was one of the indicators used in measuring the profitability for the study and it was found to be negatively related and unsatisfactory. The 
operating ratio also showed that the bank was inefficient in its operation and as a result, incurred more expenses. The findings suggested some implications. Firstly, considering that the credit risk in OCBC Bank remained high, there is a need to monitor risk management, especially, in areas of the variables that had a significant impact on bank credit risk. Secondly, corporate governance in the bank also impacted the performance of the bank.

Olabamiji and Michael (2018) examined the influence of credit management practices on the financial performance of Nigerian banks with specific reference to First Bank Plc. Data was collected using a Purposive sampling technique from thirty (30) respondents as a sample size used to collect data from the respondents. Both descriptive and inferential statistics were used to analyze data, such as frequency, percentage, weighted mean score, and multiple regression. The result revealed that credit management practices have a significant positive influence on the financial performance of First Bank. The study concluded that client appraisal, credit risk control, and collection policy are major predictors of the financial performance of the First Bank. Subsequently, the study recommended that the management of other banks should learn from the First Bank by enhancing their client appraisal techniques, credit risk control, and adopting a more stringent policy to improve their financial performance.

Ahmad (2018) carried out a study to examine the impact of risk management practices on the profitability of Jordanian Deposit Money banks, using a sample of 13 Jordanian Deposit Money banks during the period (2010-2015). Data regarding variables were collected from the annual financial statements of the sample study. Return on assets represented the profitability of banks, while risk management practices consisted of liquidity, operational, credit and market risks. The study used two ratios to symbolize each type of risk. The ordinary least square method (Fixed effect and Random effect) was used to test the hypothesis. The study revealed that risk management practices as a whole, explains a significant part of the variation in banks' profitability. The results also showed that only financial risk management practices significantly affected the profitability, while liquidity, credit and market risks have an insignificant effect. The implications of the results indicated that Jordanian Deposit Money banks (JCB) have successfully managed liquidity, credit, operating income and market risks during the study period, but at the same time failed to manage financial risk represented in overheads

Imad (2017) conducted a study to analyze the impact between credit risk and the profitability of five banks on the Palestine Exchange. The study used data collected from the financial statements of five out of the six listed banks on the Palestine Exchange for a period of 6 years from 2010 to 2015. In order to ensure that the data does not suffer from multicollinearity, the study tested for Variance Inflation Factor (VIF) in addition to the Tolerance test, and the test was satisfactory. Profitability was measured by using a return on equity and return on assets while credit risk was measured by net charge-offs to total loans and advances, non-performing loans to total loans and advances, and pre-provision profit to total loans and advances. Other variables such as bank size, leverage, and net income growth were included to account for their effects. The study found a weak but positive relationship between credit risk, as measured by non-performing loans to total loans and advances, and profitability as measured by return on assets. The study also found that bank size was positively related to profitability. 


\section{Ml Macrothink}

Asian Journal of Finance \& Accounting

ISSN 1946-052X

2020, Vol. 12, No. 2

Table 4.1. Measure of Variables

\begin{tabular}{|c|c|c|c|}
\hline Variables & Abbrev & Measurement & Source \\
\hline \multicolumn{4}{|l|}{$\begin{array}{l}\text { Dependent Variables } \\
\text { (Equity Returns) }\end{array}$} \\
\hline Return on Equity & ROE & $\frac{\text { Net Profit After Tax }}{\text { Shareholder's Equity }}$ & $\begin{array}{l}\text { Aguguom \& Salawu } \\
\text { (2018) }\end{array}$ \\
\hline Return On Assets & ROA & $\begin{array}{c}\text { NPBIT } \\
\text { Total Assets }\end{array}$ & Biswas (2016) \\
\hline \multicolumn{4}{|c|}{$\begin{array}{l}\text { Independent Variables } \\
\text { (Operational Risk) }\end{array}$} \\
\hline Credit Risk & $\mathrm{Cr}$ & $\frac{\text { Bad \& Doubtful Loan Provisions }}{\text { Total Loans }}$ & Gadzo et al. (2019) \\
\hline Insolvency Risk & Insor & $\begin{array}{l}\text { Total Loans } \\
\text { Total Assets }\end{array}$ & $\begin{array}{c}\text { Jilkoya \& Stranska } \\
\text { (2017) }\end{array}$ \\
\hline Liquidity Risk & LQR & $\frac{\text { Short Term Security }}{\text { Total Deposit }}$ & Olalere et al. (2018) \\
\hline Controlling Variable & & & \\
\hline Firm Size & Frmsiz & $\begin{array}{l}\text { Log Of Total Assets } \\
\text { (Absolute Fig) }\end{array}$ & Gadzo et al., (2019 \\
\hline
\end{tabular}

Source: Researcher' Compilation (2020).

\section{Methodology}

This study investigated the effect of operational risk on equity returns of Deposit Money Banks, using a population which consisted of 19 listed deposit money banks in the Nigeria Stock Exchange. 15 deposit money banks were purposively selected for a period of 15 years 2005 and 2019. Descriptive and inferential statistics were explored for the data analysis sourced from the published financial statements of the banks. The application of the Hausman test provided the criteria for choosing between Random Effect Models and Fixed Effect Model. Breusch and Pagan Lagrangian multiplier test was employed to confirm the Hausman test's result in order to decide between Random Effects and Pooled OLS. Three models were estimated based on the three proxies of the dependent variable. The first equation is the one which considers the return on equity (ROE) and returns on assets (ROA) as the performance indicator of equity returns, while credit risk, liquidity risk (LQR), and insolvency risk (INSR) are controlling variable of firm size (FSIZE).

\section{Research Hypotheses}

Ho1: Operational risk has no significant effect on equity returns (ROE) of deposit money banks

$\boldsymbol{H}_{0}$ 2: Operational risk with control variable of firm size has no significant effect on equity returns (ROE) of deposit money banks in Nigeria.

Ho3: Operational risk has no significant effect on return on assets (ROA) of deposit money banks in Nigeria. 


\section{Macrothink}

$H_{04}$ : Operational risk with control variable of firm size has no significant effect on return on assets (ROA) of deposit money banks in Nigeria

\section{Functional Relationship}

$\mathrm{Y}_{\mathrm{it}}=\beta_{0}+\beta \mathrm{XZ} \mathrm{Z}_{\mathrm{it}}$

$\mathrm{Y}=$ Dependent Variable: Equity Returns

$\mathrm{X}=$ Independent Variable: Operational Risk

$\mathrm{Z}=$ Controlling Variable: Firm Size

\section{Model Specification}

$$
\begin{array}{cr}
L_{\text {OGNROE }}=\beta_{0}+\beta_{1} \Delta L O G R O E_{i t}+\beta_{2} L O G C R_{i t}+\beta_{3} L O G I N S R_{i t}+\beta_{4} L O G L Q R_{i t}+\varepsilon_{i t} & \text { Model } 1 \\
L O G R O E_{i t}= & \beta_{0}+\beta_{1} \Delta L O G N P M R_{i t}+\beta_{2} L O G C R_{i t}+\beta_{3} L O G I N S R_{i t}+\beta_{4} L O G L Q R_{i t}+\beta_{5} F S I Z E_{i t}+ \\
\beta_{5} \Delta F S I Z E_{i t}+\varepsilon i t & \text { Model } 2 \\
R O A_{i t}=\beta_{0}+\beta_{1} C R_{i t}+\beta_{2} L O G I N S R_{i t}+\beta_{3} L Q R_{i t}+\varepsilon i t & \text { Model } 3 \\
R O A_{i t}=\beta_{0}+\beta_{1} C R_{i t}+\beta_{2} L O G I N S R_{i t}+\beta_{3} L Q R_{i t}+\beta_{4} F S I Z E_{i t}+\varepsilon i t & \text { Model } 4
\end{array}
$$

Where: $\mathrm{ROE}=$ Return on equity; ROA $=$ Return on Assets; $\mathrm{CR}=$ Credit Ratio; INSR $=$ Liquidity Risk; LQR

\subsection{Descriptive Analysis_}

This section describes the variables used in this study. The variables are presented in three (3) different subsections. Subsections (1) and (2) focus on the description of dependent and independent variables, respectively, in terms of the number of observations, mean, median, maximum, minimum, and standard deviation. In addition, subsection (3) focuses on the description of the associations that exist among the selected variables.

\subsubsection{Summary Statistics - Indicators (Dependent Variables)}

This subsection focuses on the description of the variables that are considered as dependent variables in the subsequent analysis. The dependent variables are returned on equity (ROE), and Return on Assets (ROA), and they are used as indicators or proxies for measuring equity returns of the selected listed DMBs in Nigeria. 
Table 4.1. Summary Statistics - Indicators (Dependent Variables)

\begin{tabular}{ccc}
\hline & ROE & ROA \\
\hline Observations & 225 & 225 \\
\hline Mean & 602.1182 & 0.5403 \\
\hline Median & 506.4328 & 0.0237 \\
\hline Maximum & 4780.6030 & 30.5852 \\
\hline Minimum & -131.5863 & -0.1021 \\
\hline Std. Dev. & 610.7984 & 3.4302 \\
\hline
\end{tabular}

\section{Source: Author's Computation (2020).}

\section{Return on equity}

From the result in Table 4.1, the average value of ROE is 0.8111 while the median value is 0.8787 , suggesting that the selected listed DMBs' average ROE during the period of this the study was $81.1 \%$. This means that the listed DMBs were able to make $81 \%$ profit from their shareholders investment. The slight difference between the average and median values suggests that the performance ratio of the selected DMBs is not quite different from one bank to another. The maximum value of ROE of the selected bands is approximately 2 million and in percentage, it implies that some of the selected DMBs recorded more than $100 \%$, specifically $202 \%$ within the period of the study, and the level of deviation between the selected banks is approximately $31 \%$ during the period.

\section{Return on Assets}

It can be seen from the table that the average percentage of ROA is $54 \%$. While the maximum and the minimum distributions of the series (ROA) are 30.6 million and -0.1 million, respectively, the standard deviation between the value of ROA among the listed DMBs are 3.4 million. By implications, the level of equity returns of the selected banks differs from one another, and the extent of operational risk management among these banks vary as well.

\subsubsection{Summary Statistics - Indicators (Independent Variables)}

Operational risk is the independent variable in this study. The summary statistics of the various proxies used for operational risk management of the selected deposit money banks are presented in Table 4.2. The independent variables are Credit Risk (CR), Insolvency Risk (INSR), and Liquidity Risk (LQR), while firm size (FSIZE) was used as a controlled variable. 


\section{Macrothink}

Table 4.2. Summary Statistics - Indicators (Independent Variables)

\begin{tabular}{l|llll}
\hline & CR & INSR & LQR & FSIZE \\
\hline Observations & 225 & 225 & 225 & 225 \\
Mean & 0.761993 & 1.630116 & 1.911175 & 7.351349 \\
Median & 0.753594 & 1.632801 & 1.841115 & 6.711791 \\
Maximum & 1.519670 & 4.633305 & 4.004754 & 9.671570 \\
Minimum & 0.129087 & 0.744469 & -0.398530 & 3.694956 \\
Std. Dev. & 0.193659 & 0.434723 & 0.486193 & 1.451314 \\
\hline
\end{tabular}

Source: Author's Computation (2020).

\section{Credit Risk}

In Table 4.2, it can be seen that the computed average credit risk ratio for the selected DMBs in the Nigerian Stock exchange during the years under study stood at 0.761993 , its median is 0.754 , and the maximum is 1.519 while the minimum distribution is 0.129 . This distribution shows that the mean and mid amount of CR of the banks are closely related and the amount of deviation of CR among the banks is $19.4 \%$. The indication from the above is that the average and mid amount of CR are $76.26 \%$ and $75.4 \%$ respectively. This implies that the level of the credit risk of the selected DMBs is high and that there is a need for prudent financial management to diminish overall operational risk of the banks.

\section{Insolvency Risk}

In Table 4.2, the average INSR recorded by the selected banks within the study period 1.63. This means that the extent of the average annual insolvency risk is over $100 \%$ (163\%) at the aggregate level for the selected banks. The minimum and maximum value of INSR is 0.744 and 4.633 representing $74.4 \%$ and $463.3 \%$. The median value of the distributed is $163.3 \%$, while the level of the standard deviation of INSR among the selected banks is approximately

\section{Liquidity Risk}

From the above table, the maximum value of LQR is $4.005(400.5 \%)$ while the minimum value is -0.398$)(-40 \%)$. The median value of the distribution is $1.841(181.4 \%)$ and overall average distribution of $1.911(191.1 \%)$. These figures depict that there was a decline of about $40 \%$. The banks are therefore expected to constantly decrease sources of inefficiencies in their risk management.

\section{Firm Size}

This is used as the control variable in this study. The distribution of this series is summarized in the table above. It is indicated that within the period of the study, the selected banks have recorded an average of $7.4 \%$ increase in total assets. Since the firm size is obtained as a logarithmic transformation of the total assets of the listed firms, it is expressed in percentage. 


\section{Al Macrothink Institute $^{\mathrm{TM}}$}

Therefore, the maximum level of increase in firm size is $9.7 \%$ while the minimum is $3.7 \%$. The level of deviation between firms' size of the listed banks is $1.5 \%$, hence, the selected banks have closely related firm sizes. This is further varied as the percentage of maximum firm size and the median firm size is close to each other and the banks are relatively large as the standard deviations of the cross-sections of firm size only $1.5 \%$.

\subsubsection{Correlation Matrix and Interpretations}

This subsection focuses on the results of the correlation analysis that depicts the degree of associations among the selected variables in this study. The correlation result relates to the level of associations of the proxies of equity returns and measures of operational risk. This correlation analysis helps identify those time series variables that either has negative or positive association with each other, and the extent of their relationship in order to further, determine whether the correlation can cause multicollinearity problem in the subsequent empirical analysis.

Table 4.3. Correlation Matrix and Interpretations

\begin{tabular}{|c|c|c|c|c|c|c|}
\hline$V A R$ & $\begin{array}{c}R O E \\
\text { (1) }\end{array}$ & $\begin{array}{c}R O A \\
(2)\end{array}$ & $\begin{array}{l}\text { CR } \\
\text { (3) }\end{array}$ & $\begin{array}{c}\text { INSR } \\
\text { (4) }\end{array}$ & $\begin{array}{c}L Q R \\
(5)\end{array}$ & $\begin{array}{c}\text { FSIZE } \\
\text { (6) }\end{array}$ \\
\hline$R O E$ & 1.000 & & & & & \\
\hline$R O A$ & -0.024 & 1.000 & & & & \\
\hline$C R$ & -0.029 & 0.291 & 1.000 & & & \\
\hline INSR & -0.021 & 0.707 & -0.023 & 1.000 & & \\
\hline$L Q R$ & -0.029 & -0.027 & -0.030 & -0.023 & 1.000 & \\
\hline$F S I Z E$ & 0.144 & -0.241 & -0.238 & -0.147 & 0.082 & 1.000 \\
\hline
\end{tabular}

Source: Author's Computation (2020).

The result in column (1) to (3) of Table 4.3 shows that the associations among the dependent and independent variables absolutely take values between 0.020 and 0.144 . It is pertinent to mention here that not any of these correlation coefficients suggest a multicollinearity problem. Multicollinearity problem occurs only when there are high correlations among independent variables. Specifically, in column (1) of the Table; all the correlation coefficients with the exception of firm size (FSIZE) are negatives indicating that increasing risk exposures of the DMBs will lead to less equity returns. While the positive correlation coefficient of $0.144(14.4 \%)$ between firm size and Return on equity (ROE) potentially shows that as firm size increase, the level of marginal profit will increase, some measures of risk, especially credit risk (CR) and Liquidity risk (LQR) show the same magnitude of association with ROE, 
implying that CR and LQR would likely have a similar negative effect on the level of equity returns of the selected listed banks. In all, it is evidenced by the correlation coefficients in the table that there are predominantly negative relationships between measures of operational risks and equity returns measures.

\subsection{Inferential Statistics}

Table 4.4. Regression Result of the Effect of Operational Risk on Equity Returns

\begin{tabular}{|c|c|c|c|c|c|c|c|c|}
\hline \multirow[t]{3}{*}{ Variable } & \multicolumn{4}{|c|}{$\begin{array}{l}\text { Panel Regression Result Random Effect } \\
\text { Model without Control Variable } \\
\text { (Model 1) }\end{array}$} & \multicolumn{4}{|c|}{$\begin{array}{l}\text { Panel Regression Result Fixed Effect } \\
\text { Model with Control Variable } \\
\qquad \text { (Model 2) }\end{array}$} \\
\hline & \multicolumn{8}{|c|}{ Dependent Variable $=$ LOGNPMR } \\
\hline & Coeff. & $\begin{array}{l}\text { Robust } \\
\text { Std. } \\
\text { Error. }\end{array}$ & t-Stat. & P-value & Coeff. & $\begin{array}{l}\text { Robust } \\
\text { Std. } \\
\text { Error. }\end{array}$ & t-Stat. & P-value. \\
\hline $\mathrm{C}$ & $1.672 *$ & 0.235 & 7.114 & 0.000 & $1.897^{*}$ & 0.405 & 4.678 & 0.000 \\
\hline$\Delta($ LOGROE $)$ & $0.402 *$ & 0.064 & 6.270 & 0.000 & $0.383 *$ & 0.059 & 6.462 & 0.000 \\
\hline LOGCR & $-0.007^{*}$ & 0.001 & -4.770 & 0.000 & $-0.008^{*}$ & 0.002 & -4.989 & 0.000 \\
\hline LOGINSR & -0.036 & 0.055 & -0.665 & 0.508 & $-0.129 * *$ & 0.057 & -2.249 & 0.027 \\
\hline LOGLQR & $-0.152 * *$ & 0.065 & -2.345 & 0.021 & $-0.175^{* *}$ & 0.065 & -2.703 & 0.008 \\
\hline FSIZE & & & & & 0.010 & 0.041 & 0.248 & 0.805 \\
\hline \multirow[t]{2}{*}{$\Delta(\mathrm{FSIZE})$} & & & & & -0.063 & 0.041 & -1.564 & 0.121 \\
\hline & \multicolumn{4}{|c|}{$\begin{array}{c}\quad \text { Adj. } \boldsymbol{R}^{2}=0.535 ; \\
\text { F-Stat }=9.955(0.000)\end{array}$} & \multicolumn{4}{|c|}{$\begin{array}{c}\text { Adj. } \boldsymbol{R}^{2}=0.435 ; \\
\text { F-Stat }=6.645(0.000)\end{array}$} \\
\hline Hausman Test & \multicolumn{4}{|c|}{$2.239(0.692)$} & \multicolumn{4}{|c|}{$32.521(0.000)$} \\
\hline BP LM Test & \multicolumn{4}{|c|}{$80.690(0.000)$} & \multicolumn{4}{|c|}{$52.700(0.201)$} \\
\hline PCD test & \multicolumn{4}{|c|}{$-1.597(0.110)$} & \multicolumn{4}{|c|}{$2.984(0.003)$} \\
\hline
\end{tabular}

Source: Author's Computation (2020). Note: * and ** represent $1 \%$ and $5 \%$ level of statistical significance.

\subsubsection{Hausman Tests and Breusch and Pagan LM Test}

As in Table 4.4 in model 1, the Hausman test result without the control variable is not significant $(\mathrm{P}$-values $>0.05)$. This suggests the acceptance of the null hypothesis and that the 
random effects estimator is appropriate in investigating the effect of operational risk on the financial performance of the listed DMBs in Nigeria. However, the Breusch and Pagan LM Test employed to confirm the results of Hausman tests further strengthened the decision to use the random effect model as its estimated value is statistically significant. By this, the null hypothesis underlying the BP LM test is rejected and that the Pooled OLS cannot be used. Therefore, the Random Effect model is considered as the most appropriate and used for the analyses of the model in panel 1 without the control variable.

For the model with the control variable in a panel in model 4 of Table 4.4, the Hausman test result is statistically significant with P-values $<0.05$. This implies the rejection of the null hypothesis and the suggestion is that the fixed effect model is the best. On the contrary, however, the Breusch and Pagan LM Test (B-P LM) result is not statistically significant and this implies that Pooled OLS should be used. The comparison of the F-test and the adjusted coefficient of the determination $\left(\mathrm{Adj} . \mathrm{R}^{2}\right.$ ) the pooled and fixed-effect model, however, suggests that the fixed effect model is the best. Therefore, the Fixed Effect model is reported for the effect of operational risk on equity returns (ROE) of the selected DMBs with firm size as the control variable in panel 2.

\subsubsection{Cross-Sectional Dependence Test}

In this study, Pesaran CD test statistic results in Table 4.4 are meant to check whether the estimated models have cross sectional dependence or not when Return on equity (ROE) is regressed on Credit Risk (CR), Insolvency Risk (INSR), and Liquidity risk (LQR), as well as Firm Size (FSIZE). From the Table above, the PCD test value in the model without the control is statistically insignificant, and it strongly suggests the acceptance of the null hypothesis of no cross-sectional dependence in the model. The PCD test for the model with control variable shows that there is a cross-sectional dependency of the units examined because the test is statistically significant. The implication is that the selected listed DMBs are in the same sector, hence there is an unobserved common factor among the non-stationary panels of the selected banks.

Following the post-estimation tests' results carried out, the results of the random and fixed effects model with and without the control variable, are analyzed and discussed.

\section{Model one}

$$
\begin{aligned}
& L O G R O E_{i t}=\beta_{0}+\beta_{1} \Delta L O G R O E_{i t}+\beta_{2} L O G C R_{i t}+\beta_{3} L O G I N S R_{i t}+\beta_{4} L O G L Q R_{i t}+\varepsilon i t-\text { Model } 1 \\
& R O E_{i t}=1.672+0402 R O E_{i t}-0.007 C R_{i t}-0.036 I N S R_{i t}+0.152 L Q R_{i t}+e_{i t}
\end{aligned}
$$

Using Dynamic Model: In column (1) of Table 4.4, the significant value of F-statistics [9.955; $\mathrm{P}$-value $=0.000]$ shows that the selected random effect model is statistically significant. That is, the combined effect of CR, INSR, and LQR on ROE is statistically significant at $5 \%$ level of statistical significance. The adjusted coefficient of the multiple determinations $\left(\operatorname{Adj} . R^{2}=0.535\right)$ further confirmed the usefulness of the model. The Adjusted R-square value of 0.535 indicates that the explanatory variables jointly account for about $54 \%$ of the variation in Return on equity 
of the selected listed banks. This evidence, therefore, indicate that operational risk has a significant effect on equity returns of DMBs in Nigeria.

Focusing on the coefficient of individual parameters (independent variables), the dynamic coefficient of the dependent variable which is the change in the logarithmic value of Return on equity $\Delta$ (LOGROE) is statistically significant at $5 \%$ and it shows if change if ROE of the selected banks increase by $1 \%$, it will cause the current value of ROE to increase by $0.4 \%$. Also, if all things being equal, the result indicated that a $1 \%$ increase in the coefficient of the log value of credit risk (CR) will lead to a $0.01 \%$ decrease in ROE. It is also found from the result in panel 1 of Table 4.4 that a $1 \%$ increase in Liquidity risk of the banks will lead to about a $0.2 \%$ decrease in equity returns of the banks. The result for the coefficient of insolvency risk is not significant although it shows that an increase of $1 \%$ in insolvency risk will potentially decrease equity returns of the banks by $0.04 \%$. Overall, two of these proxies of operational risk validate the point that operational risk has significant negative impacts on equity returns of DMBs in Nigeria.

\section{Model Two}

$$
\begin{aligned}
& L O G R O E_{i t}=\beta_{0}+\beta_{1} \Delta L O G R O E_{i t}+\beta_{2} L O G C R_{i t}+\beta_{3} L O G I N S R_{i t}+\beta_{4} L O G L Q R_{i t}+\beta_{5} F_{S I Z E_{i t}}+
\end{aligned}
$$

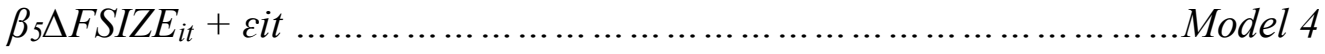

$$
\begin{aligned}
& R O E_{i t}=1.897+0.383 L_{O G R O E_{i t}}-0.008 L_{O G C R_{i t}}+0.129 \text { LOGINSR }_{i t}+0.175 \text { LOGLQR }_{i t}
\end{aligned}
$$

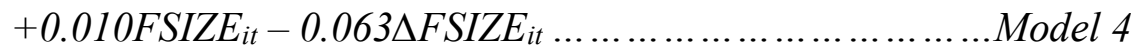

In column (1) of Table 4.4, the significant value of F-statistics $[6.645 ; P$-value $=0.000]$ indicates that the selected results in the fixed effect model are statistically significant and that the joint effects of the regressors (independent variables) which are CR, INSR and OPIR on ROE is statistically significant at $5 \%$. It is further supported by the adjusted value of the coefficient of the determination of the model $\left(\operatorname{Adj} . R^{2}=0.435\right)$. This indicates that the proxies of operational risk jointly accounted for about $44 \%$ of variation in the dependent variable-Return on equity (ROE) of the selected listed banks. By implication, operational risk has a significant effect on equity returns of DMBs in Nigeria.

In terms of individual significance of the explanatory variables, the result indicates that the dynamic coefficient of the dependent variable, which is the change in the logarithmic value of ROE, is statistically significant at $5 \%$ with the implication that a $1 \%$ increase in equity returns of the banks will trigger current value of profit margin to increase by $0.4 \%$. In other words, a positive change in profit margin of DMBs in Nigeria increases the equity returns of the banks. On the part of credit risk (CR), the result demonstrates that a $1 \%$ increase in CR of the banks will lead to about $0.01 \%$ decline in net profit margin of the selected listed deposit money banks in Nigeria.

The control variable, which is firm size (FSIZE), established an insignificant impact on equity returns of the selected banks. In fact, the value of firm size and the coefficient of its change (dynamics), indicated insignificant effects on the ROE of the firms. Since the joint impact measures of the model with the firm size are significant, it implies that firm size can potentially increase the level of equity returns of the banks. This is confirmed from the positive coefficient 
of the variables. For instance, a 1\% increase in FSIZE will potentially increase the ROE of the banks by about $0.01 \%$. Also, a $1 \%$ change in firm size will potentially lead to a decrease of about $0.06 \%$ in ROE of the banks.

\section{Discussion of Findings (Models 1 \& 2)}

The findings from the regression result in Table 4.4 reveal that negative relationships exist between Credit risks (CR), Insolvency risk (INSR), Liquidity risk (LQR), and Return on equity (ROE) in panel 1. In the same fashion, CR, INSR, and LQR portrayed negative impacts on net profit margin of the banks in the fixed-effect model with control variable in panel 4 . This result is consistent with the findings of Lyambiko (2015) who established that CR and INSR as indicators of operational risk had negative effects on the financial performance of Deposit Money banks in Tanzania. Also, the findings of this study is consistent with Muriithi and Muigai (2017) on quantitative analysis of operational risk and equity returns of Kenyan Deposit Money Banks using cost income ratio, indicated that cost income is negatively influenced bank equity returns both in the long run and short run. Like the findings of negative impacts of operational risks on banks' performance in Nigeria in this study, Olalere and Wan (2018) obtained similar findings in their study. They empirically found that effects of credit risk on equity returns of Deposit Money Banks in Nigeria were evidently negative and significant. 
Table 4.6. Regression Result of the Effect of Operational Risk on Return on Assets

\begin{tabular}{|c|c|c|c|c|c|c|c|c|}
\hline \multirow{3}{*}{ Variable } & \multicolumn{4}{|c|}{$\begin{array}{l}\text { Panel Regression Result } \\
\text { Random Effect Model without Control } \\
\text { Variable } \quad \text { (Model 3) }\end{array}$} & \multicolumn{4}{|c|}{$\begin{array}{l}\text { Panel Regression Result Fixed Effect } \\
\text { Model with Control Variable } \\
\text { (Model 4) }\end{array}$} \\
\hline & \multicolumn{8}{|c|}{ Dependent Variable $=\mathrm{ROA}$} \\
\hline & Coeff. & $\begin{array}{l}\text { Robust } \\
\text { StdErr }\end{array}$ & t-Stat. & P-value & Coeff. & $\begin{array}{l}\text { Robust } \\
\text { StdErr. }\end{array}$ & t-Stat. & P-value. \\
\hline $\mathrm{C}$ & $-839.907 *$ & 88.661 & -9.473 & 0.000 & 290.296 & 280.920 & 1.033 & 0.304 \\
\hline $\mathrm{CR}$ & $0.099 *$ & 0.021 & 4.762 & 0.000 & $0.042 * * *$ & 0.024 & 1.804 & 0.074 \\
\hline LOGINSR & $536.688^{*}$ & 52.300 & 10.262 & 0.000 & $524.610^{*}$ & 53.722 & 9.765 & 0.000 \\
\hline LQR & -0.0000013 & 0.000 & -0.005 & 0.996 & -0.00023 & 0.00023 & -0.986 & 0.327 \\
\hline \multirow[t]{2}{*}{ FSIZE } & & & & & $-148.914^{*}$ & 34.535 & -4.312 & 0.000 \\
\hline & \multicolumn{4}{|c|}{$\begin{array}{c}\text { Adj. } \boldsymbol{R}^{2}=0.520 \\
\text { F-Stat }=10.187(0.000)\end{array}$} & \multicolumn{4}{|c|}{$\begin{array}{c}\text { Adj. } \boldsymbol{R}^{2}=0.581 \\
\text { F-Stat }=13.678(0.000)\end{array}$} \\
\hline Hausman Test & \multicolumn{4}{|c|}{$4.697(0.195)$} & \multicolumn{4}{|c|}{$18.924(0.000)$} \\
\hline BP LM Test & \multicolumn{4}{|c|}{$174.844(0.000)$} & \multicolumn{4}{|c|}{$168.334(0.000)$} \\
\hline PCD test & \multicolumn{4}{|c|}{$2.805(0.005)$} & \multicolumn{4}{|c|}{$2.677(0.007)$} \\
\hline
\end{tabular}

Source: Author's Computation (2020). Note: ${ }^{*}, * *$ and $* * *$ represent $1 \%, 5 \%$, and $10 \%$ level of significance.

\subsubsection{Hausman Tests and Breusch and Pagan LM Test}

Results in Table 4.6 reveal that the estimated coefficient of the Hausman test shows insignificant with the P-value of 0.195 . This suggests the acceptance of random effect model in panel 1 without the control variable for investigating the effect of operational risk on the financial performance of the listed DMBs in Nigeria in terms of Return on Assets (ROAs). To be able to choose between Random effect Model and Pooled OLS, however, the result for the B-P LM test confirms that the best model is Random effect as its P-value was significant $(P$-value $<0.05)$. Therefore, the Random Effect model is used for the analyses of the model in panel 1 without the control variable.

For the model with the control variable of firm size in panel 6 of Table 4.6, the Hausman test result is statistically significant $(P$-values $<0.05)$. This requires that the null hypothesis is rejected and that the fixed effect model is the best. The B-P LM test reveals that Pooled OLS 
cannot be used as the P-value $<0.05$ is statistically significant. Therefore, the Fixed Effect model is the best and is reported for the effect of operational risk on equity returns (ROE) of the selected DMBs with firm size as the control variable in panel 2.

\subsubsection{Cross-Sectional Dependence Test}

Evidence for the existence of cross-sectional dependence is checked with the use of PCD test statistics for the model with and without control variable. The result in panel 3 and 6 show that there is a presence of cross-sectional dependence of the estimates for the selected banks. By implication, the sampled Banks may have common heterogeneous factors that determine their financial performances and risk management.

Based on these diagnostics or post-estimation tests' results, the results of the random and fixed effects model with and without the control, variable are analyzed and discussed and the models reinstated as:

\section{Model Three}

$$
\begin{aligned}
& R O A_{i t}=\beta_{0}+\beta_{1} C R_{i t}+\beta_{2} L O G I N S R_{i t}+\beta_{3} L Q R_{i t}+\varepsilon_{i t} \quad \ldots \ldots \ldots \ldots \ldots \ldots \ldots \ldots \ldots \ldots \text {...................... } 3 \\
& R O A_{i t}=-839.907+0.099 C R_{i t}+536.688 L O G N S R_{i t}+0.003 L Q R_{i t}+\varepsilon_{i t} \ldots \ldots \ldots \ldots \ldots \text {...... }
\end{aligned}
$$

In column (1) of Table 4.6 above, the overall joint test of significant, F-statistics [F-Stat = 10.187; P-value $=0.000$ ] shows that the selected random effect model is statistically significant, and it implies that the measures of operational risk (CR, INSR, and LQR) had a statistically significant combined effect on ROA of the selected listed banks at a 5\% level of significance. The adjusted R-Square which is the coefficient of the determination of the model shows that the independent variables jointly determine variation in ROA for about $52 \%$. That is, other variable that is not included as part of the independent variable account for about $48 \%$ of total variations in Return on Assets (ROA) of DMBs. In all, the included measures of operational risk of the banks are statistically significant in determining the extent of ROA of the banks.

Since the estimated model in Table 4.6 is a semi-log model, that is a Linear-Log model, evidence from the estimates of the independent variables reveals that a unit increase in Credit Risk (CR) will lead to 0.099 unit increase in ROA of the banks. Similarly, if insolvency risks (INSR) increase by $1 \%$, it will cause about 5.37 unit (i.e. 536.688/100) change in the average value of ROA for the selected DMBs in Nigeria. The coefficient for the value of Liquidity risk is insignificant; however, it reveals that a unit increase in Liquidity risk will decrease ROA of the banks by 0.0000013 units. It is only credit risk (CR) and insolvency risk (INSR) that showed a positive impact on ROA. The overall indication from the analysis above, therefore, shows that operational risk has significant positive effects on equity returns of DMBs in Nigeria.

\section{Model Four}

$$
\begin{aligned}
& R O A_{i t}=\beta_{0}+\beta_{1} C R_{i t}+\beta_{2} L O G I N S R_{i t}+\beta_{3} L Q R_{i t}+\beta_{4} F_{S I Z E_{i t}}+\varepsilon_{i t} \\
& \mathrm{ROA}_{\mathrm{it}}=290.296+0.042 \mathrm{CR}_{\mathrm{it}}+524.610 \mathrm{LOGNSR}_{\mathrm{it}}-0.013 \mathrm{LQR}_{\mathrm{it}}-148.914 \mathrm{FSIZE}_{\mathrm{it}} \quad \text { Model } 4
\end{aligned}
$$




\section{Mll Macrothink}

Asian Journal of Finance \& Accounting

ISSN 1946-052X

2020, Vol. 12, No. 2

Results in Panel 4 in Table 4.6 implies that the joint F-statistic that measures the overall significant of the explanatory variables is 13.678 with $P$-value $=0.000$ and it implies that the indicators of operational risk with firm size as the control variable are jointly significant in predicting Return on Assets (ROA) of the banks. The adjusted R-square $\left(\operatorname{Adj}^{2}=0.581\right)$ indicates that all the independent variables including the control, significantly accounted for overall $58.1 \%$ variation in ROA of the selected DMBs in Nigeria.

With reference to individual performances of the regressors, the results in Table 4.6 with the control exhume that at a $10 \%$ level of statistical significance, a unit increase in CR will lead to 0.042 units increase in ROA of the selected banks. For insolvency risk, a 1\% increase in the level of insolvency of the banks will cause 5.23 units to rise in the average value of ROA of the banks. Again, the coefficient for Liquidity risk is not significant, but it potentially shows that if a unit changes in LQR could cause ROA to decrease by 0.00023 units.

The control variable, firm size (FSIZE) proves to be statistically significant as a determinant of the financial performance of the selected DMBs in Nigeria. In this case, the result indicates that a unit increase in firm size will decrease ROA of the banks by 149 units, approximately. This result suggests that increase in firm size, which is measured as a logarithmic transformed value of total assets without a significant corresponding rise in gross earnings, will decrease the ROA of the banks. Therefore an augmented model of operational risk impact on banks equity returns with firm size as a control variable is significantly robust.

\section{Discussion of Findings (Model 3 \& 4)}

The findings from the regression result in Table 4.6 reveal that negative relationships exist between credit risks (CR) and Return on equity (ROE) of the banks, and Liquidity risk (LQR) and ROE in panel 3. In the same fashion, CR, INSR and LQR portrayed negative impacts on net profit margin of the banks in the fixed effect model with a control variable in panel 6 . This result is consistent with the findings of Sempabwa and Kariuk (2017) who found in their study on Rwandan enterprise risk management practices and financial performance of Deposit Money banks with simple regression analyses, that credit risk management had a positive influence on the financial performance of Rwandan's Deposit Money Banks. Also, Arnet, Gregory and Maurice (2016) who studied the effect of risk management practices on the financial performance of DMBs in Kenya although a positive statistically significant relationship between risk management practices and financial performance of DMBs in Kenya was established. The result found which was found in this study for hypothesis three corroborates with the findings of other authors such as Nurlida (2017) who conducted a study on operational risks in Malaysia. By employing credit risk ratio, liquidity ratio, operational risk ratio, and performance indicators of return on asset ratio, return on equity ratio, net interest margin as was used for a period of 5 years (2011-2015), this author found that risk management positively affected performance of DMBs in Malaysia. 


\section{Conclusion, Recommendations and Contribution to Knowledge}

\subsection{Conclusion}

This study examined the effect of operational risk on equity returns, applying dynamic and static panel data analysis. The study formulated and tested four models of the effect of operational risk on net profit margin for Model 1, and the effect of operational risk on return on assets for Model 2. The control variable of firm size was introduced to each of the models for Models 3 and 4. The aim was to determine the reaction of the models. The results revealed that operational risk had a statistically positive significant effect on Return on equity in model 1 , while operational risk exerted positive statistical effect also on return on assets. The control variable on each of the models revealed operational risk with firm size exhibited statistical positive significance on each of the Return on equity and return on assets. Conclusively, the study affirms that equity returns were statistically affected by operational risk in Nigeria.

\subsection{Recommendations and Contribution to Knowledge}

The study recommends that DMBs managers should carefully carry out due diligence on loan applicants, to ascertain performance trend and creditworthiness of potential and prospective borrowers before advancing loans in order to reduce huge profiles of credit risk exposures. Operational competence and recruitment procedure are critical for DBMs towards the reduction of operational risks. Optimal utilization of banks resources is imperative if adequate returns must be ensured. Directors should be more diligent and implement effective monitoring roles in line with the corporate governance best practices. While vast literature does exist in the area of operational risk, however, only a considerably limited work has attempted to study the effects of operational risk on equity return exploring dynamic and static panel analysis in the Nigerian emerging literature. In addressing this gap, this study has investigated the effects of operational risk on equity literature. It might be possible to expand this study to include more years of data and also extend the analysis to include more banks in further studies.

\section{References}

Aguayo, F. Z., \& Slusarczyk, B. (2020). Risks of banking services' digitalization: The practice of diversification and sustainable development goals. Sustainability, 12, 1-12. https://doi.org/10.3390/su12104040

Aguguom, T. A. (2020). Cash flow optimality and investment returns: Investors expectations in listed manufacturing firms in Nigeria. Asian Journal of Economics, Business and Accounting. 16(4), 39-50, Article no.AJEBA.59499. DOI: 10.9734/AJEBA/2020/v16i430247.

Aguguom, T. A., \& Salawu, R. O. (2018). Earnings quality and firms' book value: Empirical evidence from the listed firms in Nigeria. Journal of Internet Banking and Commerce, 23(3), $1-22$.

Ahmad, B. (2018). Effect of credit risk, liquidity risk, and market risk banking to profitability Bank; Study on devised banks in Indonesia Stock Exchange. European Journal of Business and Management, 9(29), 222-231. 
Arnet, N. M., Gregory, S. N., \& Maurice, S. (2016). Effect of risk management practices on financial performance in Kenya Deposit Money banks. Research Journal of Finance and Accounting, 1(1), 1-16.

Bank for International Settlements. (2013). Basel III: The Liquidity Coverage Ratio and liquidity risk monitoring tools. Retrieved from Bank for International Settlements: Available at: http://www.bis.org/publ/bcbs238.htm, Accessed 4th June 2020

Biswas, T. (2017). Responsibility accounting: A review of related literature. International Journal of Multidisciplinary Research and Development, 4(8), 202-206.

Buckova, V., \& Reuse, S. (2011). Basel III Global liquidity standards: Critical discussion and impact on the European banking sector.

Chaikovskyi, Y.; Kovlchuk, Y. (2019). Banking innovations: Perspectives and threats of electronic banking services. World Finance 4(1), 121-136. https://doi.org/10.35774/sf2018.04.121

Ezejiofor, R. A., Adigwe, P. K., \& John-Akamelu, R. C. (2015). The credit management on liquidity and profitability position of manufacturing company in Nigeria. European Journal of Research and Reflection in Management Sciences, 3(3), 32-48.

El-Ansary, O. (2019). Predicting financial distress for listed Middle East and Northern Africa firms. International Journal of Accounting and Financial Reporting, 9(2), 51-75. https://doi.org/10.5296/ijafr.v9i2.14542

Fox, J., \& Lorsch, J. W. (2012). What good are Shareholders? Harvard Business Reviews.

Gadzo, S. G., Kportorgbi, H. K., \& Gatsi, G. J. (2019). Credit risk and financial risk on financial performance of universal banks in Ghana: A partial least squared structural equation model approach. Cogent Economics \& Finance, 7(1), 1-16. https://doi.org/10.1080/23322039.2019.1589406

Gary, G. (2016). The impact of the Basel 3 capital requirements on the performance of European banks. Master dissertation. Ecole de Gestio de Universite de Liege

Gelter, M. (2009). The dark side of shareholder influence: Managerial autonomy and stakeholder orientation in comparative corporate governance. Harvard International Law Journal, 50(42), 129-194.

Imad, K. (2017). The impact of credit risk on the profitability of banks listed on the Palestine Exchange. Research Journal of Finance and Accounting, 8(8), 2222-2847

Institute of company Secretaries of India. (2016). Shareholders Wealth Maximization Trajectory. 2016. 5th March 2016. Available at: www.icsi.edu. Accessed 5th June 2020.

Institute of Chartered Accountants of Nigeria. (2014). Business and finance. Study pack. 2014. 12 August 2014. Available at: www.ican.org/businessandfinance/studypack. Accessed 6th June 2020 
Isoh, A. V. N., Ambang, E. M., \& Nchang, N. D. (2020). Assessing the impact of operational risk on financial performance of selected mainstream commercial banks in Cameroon. International Journal of Research in Commerce and Management Studies, 2(2), 1-16.

Jablecki, J. (2008). The impact of Basel I capital requirements on bank behavior and the efficacy of monetary policy. International Journal of Economic Sciences and Applied Research.

Jilkoya, P. \& Stranska, P.K. (2017). Multiple linear regression analyses of the performance and profitability of the Czech banking sector. Institute of Economic Research, Working Papers, 1(2).

Jones, T. M., \& Will, F. (2013). Shareholder Wealth Maximization and Social Welfare: A Utilitarian Critique. https://doi.org/10.5840/beq201323215

Knežević, M. (2013). Financial risk: Challenges for the banking industry. Economics and Accounting Journal, 46(2), 40-52

Kariuki, P., \& Peddy, P. (2017). Operationalizing an effective mentoring and evaluation system for local government: Consideration for the best practice. African Evaluation Journal, 5(2), 1-16. https://doi.org/10.4102/aej.v5i2.240

Lyambiko, M. R. (2015). The effect of financial risk management practices on financial performance in Deposit Money banks in Tanzania. The University of Nairobi Journal, 2(1), $45-58$.

Maixé-Altés, J. C. (2019). The digitalization of banking: A new perspective from the European savings banks industry before the Internet. Enterp. Soc. 20, 159-198. https://doi.org/10.1017/eso.2018.18

Mostafa, Z., Mahmoud, B., Jalal, J., \& Elahe, S. (2016). The Relationship between Financial risk and the profitability of the banks listed on the Tehran stock exchange. ICP business, economics, and finance, 3(1), 56-0.

Muhammad, Z., \& Abdul, K. (2017). Financial risk and performance: empirical evidence from OCBC Bank (Malaysia) Berhad. https://mpra.ub.unimuenchen.de/78348/. Retrieved, $12 / 4 / 2019$.

Muriithi, J. G., \& Muigai, R. G. (2017). Quantitative analysis of financial risk and profitability of Kenyan Deposit Money Banks using Cost Income Ratio. Journal of Economics and Finance, 8(3), 76-83. https://doi.org/10.9790/5933-0803047683

Nabweteme S. G. (2015). Financial risk management, organizational environment, and organizational performance at Stanbic Bank Uganda Limited. Journal of Contemporary Business and Economics, 1(1), 12-28.

Nurlida, M. A. (2017). The relationship between risk and performance in bank. Available at: https://mpra.ub.Uni-muenchen.de/78334/. Accessed 11th June 2020. 
Nwaze, C. (2011). Corruption in Nigeria exposed. (1st Ed). Control and Surveillance Associates Limited, Lagos Nigeria

Ogbuagu, U., Ubi, P., \& Effiom, L. (2014). Corruption and infrastructural decay: perceptible evidence from Nigeria. Journal of Economics and Sustainable Development, 10(5), 1-14

Olabamiji, O., \& Michael, O. (2018). Credit management practices and bank performance: Evidence from the First bank. South Asian Journal of Social Studies and Economics, 1(1), 1-10. https://doi.org/10.9734/sajsse/2018/v1i125772

Olalere, O. E. \& Wan, W. O. (2018). The empirical effects of credit risk on the profitability of Deposit Money banks: evidence from Nigeria. International Journal of Science and Research, 5(8), 1645-1650

Olaoye, S. A., \& Aguguom, T. A (2017). A tax base erosion and profit shifting through Transfer pricing: Evidence from Nigeria. Journal of Business Administration and Management Sciences Research, 6(1), 001-012.

Pracoyo, A., \& Imani, A. (2018). Analysis of the effect of capital, credit risk, and liquidity risk on profitability in banks. Jurnal Ilmu Manajemen \& Ekonomika, 10(2), 44-50 https://doi.org/10.35384/jime.v10i2.80

Sharfman, B. (2013). Shareholder Wealth Maximization and its implementation under corporate Law. Florida Law Reviews, 4th June 2013. https://doi.org/10.2139/ssrn.2129376

Sempabwa, E., \& Kariuki, P. (2017). Enterprise risk management practices and financial performance of Deposit Money Banks in Rwanda. European Journal of Business and Social Sciences, 6(6), 112 - 127 